\title{
Dewey, Mead, John Ford, and the Writing of
}

\section{History}

Pragmatist Contributions to Narrativism

\section{Verónica Tozzi}

\section{OpenEdition}

\section{Journals}

Electronic version

URL: http://journals.openedition.org/ejpap/641

DOI: 10.4000/ejpap.641

ISSN: 2036-4091

\section{Publisher}

Associazione Pragma

\section{Electronic reference}

Verónica Tozzi, « Dewey, Mead, John Ford, and the Writing of History », European Journal of Pragmatism and American Philosophy [Online], VIII-2 | 2016, Online since 16 January 2017, connection on 01 May 2019. URL : http://journals.openedition.org/ejpap/641 ; DOI : 10.4000/ejpap.641

This text was automatically generated on 1 May 2019.

\section{cc) $(1) \ominus$}

Author retains copyright and grants the European Journal of Pragmatism and American Philosophy right of first publication with the work simultaneously licensed under a Creative Commons AttributionNonCommercial-NoDerivatives 4.0 International License. 


\section{Dewey, Mead, John Ford, and the Writing of History}

Pragmatist Contributions to Narrativism

Verónica Tozzi

"The writing of History is an instance of judgment as a resolution through inquiry of a problematic

situation."

John Dewey

\section{Narrativism and New Philosophy of History}

1 The second half of the twentieth century has been witness to a blooming of reflections on the status of historical writing, and specifically narrative writing. ${ }^{1}$ As opposed to previous debates within critical philosophy of history, focused on the adequate relationship between history and the natural sciences model, ${ }^{2}$ new philosophers of history detected that historicizing the past in narrative terms does not amount to scientific underdevelopment, but is rather the expression of an autonomous form of knowledge. The works of Arthur Danto (1985), Louis Mink (1987), Hayden White (1973), Paul Ricœur (1983), Hans Kellner (1989), David Carr (1986), and Frank Ankersmit (1983 and 2002), ${ }^{3}$ despite their many differences, converge precisely in considering that the tenacious use of narration by historians does not stem from a didactic or ornamental choice, but rather it is constitutive of our way of knowing the human past. Concretely, it is largely the result of the persistent use of ordinary language that specifically describes occurrences of the human past in intentional vocabulary, something very few authors would willfully forsake. The "language of motives" (another way of naming it) is undoubtedly riddled with vagueness and ambiguity, and comes without a clear distinction between description and value and between literal and figurative. But it is precisely due to such richness that narration offers us a guarantee to understand the human in human terms. Literary theory and classical rhetoric have offered their own analysis of the diversity of figures 
and tropes that flood our everyday vocabulary; many of them even fossilize and thus seem to describe rigidly and literally various parts of our world. ${ }^{4}$

Their interest in the value of narrative to represent human past reality led all these theorists to inquire into the complexities of historical discourse and its multiple dimensions (factual or epistemic, its plot and its ideological implications). Some of them focused on detecting the myriad ways or styles of narrating and the consequences derived from such choices. Thus, the study of classical rhetoric coupled with the various strands in literary theory ${ }^{5}$ could help us deploy the mechanisms and resources involved in the production and circulation of narrative discourse. It is clear that, from this point of view, historical narratives themselves become privileged objects of analysis, since they allow us to identify their differences or similarities and thus contribute to elucidate the conflicts that arise between them. Literary theory seems to be a powerful tool able to orient us in the diversity of narrative styles and genres that historians have used since the appearance of historical writing. It seems promising to apply such dispositive, created for the analysis of literary works, to the analysis of something that goes beyond what we consider in a strict sense "literary," as is the case with disciplinary history.

As a conclusion, it is unlikely that we can solve differences between competing historical narratives by simply turning to an independent reality or exclusively to documentary evidence, since when we present the past narratively there is much more at stake than "mere reality" or "what really happened."

4 Now, these reflections have been read by critics as implying some kind of linguistic idealism - there is only language (a version of Berkeleyan idealism); some kind of linguistic determinism - whereby humans are spoken by language; antireferentialism historical knowledge does not refer to the past, it does not refer at all; and, finally, antirealism - the past historians speak about does not exist. ${ }^{6}$ As a consequence, we find an "all's fair" relativism which allows historians to say whatever they want about the past in accordance with their particular interests, since writing about the past would be nothing but "a literary or fictional exercise," also putting rational discussion about competing narratives to an end.

5 Nevertheless, we should remember that NPH does not deny the importance of documentary evidence in historical studies. ${ }^{7}$ The moral of narrativism is that one should responsibly acknowledge the fact that every configuration of the past is not limited to what already happened nor does it abide by it, and that the choice among different narratives is not solved by turning to some neutral body of evidence which could tell us which were the events that actually took place in the past. Rather, when evaluating their differences we will become involved in the deployment of all the implications of that given configuration. And literary theory, the discipline which has taken as its subject discourse in general and narrative discourse in particular, is more than apt as an instrument to guide us in deploying such consequences. ${ }^{8}$

These few observations allow us to identify the exact point where NPH is at this moment. In a few words, we could say that its achievements consist in having called attention to historical writing in itself, and reinforced the worth of an autonomous historical knowledge vis à vis standard conceptions of science which made history appear as underdeveloped. Now, although it is clear that NPH does not dismiss the importance of documentary evidence, it did not produce an integrative account of both dimensions. In other words, the work of writing and the work with evidence are not integrated as part of 
the same process of inquiry. Because, to some extent, they are slaves of some kind of epistemological dualism. On one hand, they seem to remain in the representationalist paradigm in the case of evidence, and, on the other hand, they only admit pragmatic and practical (moral) criteria in the case of narrative discourse.

In this paper I suggest that John Dewey's reflections ${ }^{9}$ on the writing of history, within the framework of his logic of scientific inquiry, offer us (Narrativist Philosophers of History) compelling keys for a rational evaluation of the contributions of literary theory for reconstructing the controversies about the interpretation of the past. According to Dewey, historical writing consists in a judgment produced as an answer to concrete problematic situations. The meanings of judgments about the past (historical narrations) "have a future reference and function" 10 and, as a consequence, their production, understanding and justification involve deploying the consequences of accepting them. I will show that these reflections allow us to consider literary theory as an unavoidable instrument to navigate all the consequences that follow from the different descriptions of the past. That is, the meaning of a proposition about the past does not refer exclusively to a past event in itself; rather, it also refers implicitly to future processes of justification. Insofar as history is writing, the science of writing (literary theory) is a key element to reconstruct such processes (the consequences that follow from descriptions themselves). Dewey's contributions will also be complemented with the reflections of his friend and colleague George $\mathrm{H}$. Mead ${ }^{11}$ about the uselessness and, thus, irrationality, of believing in the reality of a past independent from our present and from our inquiry processes. Why do I lay emphasis on rationality? Because by placing meaning in the very process of inquiry, instead of placing it in reality itself (which, by the way, could well be unattainable), we commit ourselves to being always ready to provide new and good reasons for our choices and take responsibility for their consequences. ${ }^{12}$

All of this leads us, on the one hand, to recognizing an explicit and proper pragmatist philosophy of history that, in view of contemporary debates in the field, deserves to be reconsidered. This is not a task for this paper but I need to point out that its main proponents, Mead and Dewey, are absent precisely in the debates of a discipline that is not shy about reading the classics. On the other hand, it is urgent to move forward in the development of a narrativist, pragmatistically-informed philosophy of history. This is the task that I effectively try to accomplish in this article. The alliance of narrativism with pragmatism will reinforce the most provocative - and thus more productive - thesis of the former: that the means of production of historical writing are central to elucidating controversies about the past. In my pragmatist reconstruction, narrativism affirms that the meaning of discourses about the past is not unveiled as a result of its representative relation to past reality (independently from our instruments of "representation"), but rather in terms of the future consequences of accepting such discourses as answers to problems that emerged in the context of our current practices of inquiry.

9 I have chosen to unfold the importance of the contribution of Dewey and Mead to narrativism through the analysis of the controversial case of a past event which inspired the memorable film The man who shot Liberty Valance.

\section{The Man Who Shot Liberty Valance}

10 I will begin by taking up the example of a concrete problem about the past posed by filmmaker John Ford in his memorable 1962 film The man who shot Liberty Valance. ${ }^{13}$ 
11 Old Senator Ransom Stoddard (James Stewart) returns to Shinbone, a city in the West where he had lived in his youth, right after finishing Law school in the East. He comes back to attend the burial of Tom Doniphon (John Wayne), who in 1910 was an inconspicuous man. Stoddard, on the other hand, is famous in Shinbone for being the one who, 25 years before, had shot dead the toughest thug of those times, Liberty Valance (Lee Marvin, henceforth LV).

12 A young journalist from the local newspaper, very excited about Stoddard's visit, requests an interview, which gives place to a long flashback taking us back to 1885 Shinbone. The town was driven by a typical western end-of-the-century conflict: powerful landowners who defend their "freedom" to use open lands for their cattle, against small farmers who demand State intervention to establish statehood. The main characters of this drama are Stoddard himself, supporting law and opposing the use of weapons, and Tom Doniphon, a local rancher, involuntary protector of the town due to his expertise in handling firearms. The conflict focuses on how to confront Liberty Valance, the landlords' thug who harasses small farmers into giving their lands away or selling them for almost nothing.

The story goes that Stoddard must force himself, against his principles, to accept a duel set against Liberty Valance. He shoots him dead, becomes a hero, and is chosen as town delegate for the State convention, which will be held to decide between open land or statehood. These events were followed by a great political and economical development in the town, and Stoddard builds up a prominent political career, which eventually leads him to the United States Senate.

Within Stoddard's flashback narrative we are led to a second flashback, in which he appears tormented for having violated his convictions, and unwilling to represent Shinbone. His conscience does not tolerate the fact of having killed a man. In a succession of scenes not unlike the well-known series Law and Order, Doniphon reconstructs the shooting, revealing to Stoddard that in the same second in which he shot his gun, Doniphon himself had shot his rifle, and it was the latter who killed LV. In this way, Doniphon cleaned Stoddard's conscience and suggested he did not disclose the "truth" in order not to interrupt the process that followed.

Back in 1910, Stoddard begs journalists to publish the truth in the newspaper: that it was not the bullet from his gun that killed LV, but the one shot by Doniphon with his rifle. In this way, Stoddard hopes to grant his place in history to the forgotten Doniphon. The youngest of them cannot wait to get the news in print, and this is when the old journalist pronounces the now memorable phrase "when the legend became fact, print the legend."

The case presented in this film is a clear example that illustrates our subject of inquiry, since it is founded on the presupposition that it is possible to distinguish clearly between the true and the useful. True is what is independent of our contexts and interests, and useful is what is convenient for an individual or a collective in a certain context. The old journalist's sentence, "when the legend...," obviously implies that he has chosen to solve the matter of who killed LV according to what is more convenient for the community of Shinbone, and for modern democracy in general, which needs heroes like Stoddard (a man of law) and not like Doniphon (a gunman). Moreover, one could suppose that the journalist knows the truth but prefers to conceal it; that after Stoddard's account he had the choice of bringing to light what really happened, but does not. Finally, we could also say that the journalist could have considered that the best option for the present times of 
his community was to tell the truth. ${ }^{14}$ All three options carry the unspoken assumption that - leaving aside the moral or political meaning of the stories, or their usefulness - one of them is false and the other one is not, and that this is determined by reference to what happened in 1885. Independently of how we understand usefulness or the lack of it (in moral or in plainly political terms), and independently of which are the winding paths of the proof, evidence or confessions we could collect, we must recognize that whatever makes our descriptions of the past true, it demands that an event happened before them.

In the next section, we will see the possibilities of clearly demarcating this event that serve as reference for the affirmation in past tense, and its role in deciding among conflicting affirmations by following pragmatist considerations.

\section{Dewey and the Writing of History}

Dewey addresses historical writing in the chapter "Judgment as Spatial-Temporal Determination: Narration-Description" (1938), a part of his logic of judgments. ${ }^{15}$ That is, in the context of his logic of inquiry and of the theory of the temporal and historical phase of judgment (see Dewey 1938: 246, 247). As a consequence, the specifically historical dimension of judgment, of inquiry and of the act of knowing in general come to light. His reflections primarily display the situated and active nature of inquiry. The situation frames a problem that must be addressed by a future resolution. Specifically, a judgment "consists in the transformation of the existentially indeterminate or unsettled situation into a determinate one [...]. It refers to a total qualitative situation" (Dewey 1938: 220).

This is a remarkable text, as it reveals how deeply aware our author was of the impregnable place the past holds in our lives. In this respect, he analyzes three cases of judgments about the past: namely, cases a) about one's personal past; ii) about special events that are not included in one's own experience; and iii) historical narrations (the ones that define historical inquiry or history as a science), noting the fact that in all dimensions in life, the past is always there and calls for us. For the pragmatist, the question about knowing the past is not a mere philosophical game; it is a vital problem to tackle, and this is why it should be formulated in a way that allows for an answer. Addressing the issue of the results of inquiry in terms of judgments, instead of propositions or sentences, is no minor detail either. Rather, it shows that we are thinking about the results of a concrete practice, stemming from a concrete problem - in our case, in relation to past events -, the solution of which, from the point of view of his logic of inquiry, must follow a number of requirements which will be specified throughout the inquiry itself. And this is where a common misunderstanding in relation to pragmatism must be avoided. This is not about reducing inquiry to a mere satisfaction of interests or to merely answering a question that emerges in a given context. What an analysis in terms of the logic of inquiry mandates is that, in order to evaluate any solution, we must come to terms with the consequences of accepting it. And this is why the process of justification and criticism is open, and not dogmatically sealed.

"To judge is to render determinate; to determine is to order and organize, to relate in definite fashion" (Dewey 1938: 221). The determination thus reached stemmed from a concrete problematic consideration, and therefore the resulting order cannot be evaluated without contextualizing it within the problem or situation that motivated it. Analyzing judgment (the ordering) in relation to an alleged reality independent from our ordering practices gives us no orientation as to how to evaluate such order. The 
representationalist strategy is based on a clear distinction between semantic problems (the relationship between representation and reality) and epistemic problems (criteria to find out whether the representation represents reality). On the other hand, it tends to focus on the singular existential proposition which describes singular events as an example or case of representation. According to Dewey, such a strategy provides no orientation as to how to distinguish adequate solutions to our problems of inquiry from unacceptable ones. ${ }^{16}$

Dewey characterizes judgments about the past as those in which temporal considerations are dominant. Their common trait is that they explicitly establish temporal connections: this phase is linguistically expressed in narration, ${ }^{17}$ through which "a limiting reference to both past and future is present in every existential proposition [that stresses the temporal phase of a judgment...]. Without this limitation, a change is not characterized or qualified" (Dewey 1938: 221).

The subject matter of any particular narration-description is determined by a "from which" and a "to which," and these limits are "strictly relative to the objective intent set to inquiry by the problematic quality of a given situation" (Dewey 1938: 221). When the verbal expression of an existential judgment has the past as its explicit content, the meaning of such judgment is not a past event. Expecting to analyze meaning in terms of the relationship between atomic sentences and mutually isolated events is completely arbitrary. This is because, for Dewey, any statement about the past (be it about my past, or about an event of which I had no experience, or even about a very remote event I could not possibly have experienced), if empirically gronded, will be mediated, and will depend on probatory data (see Dewey 1938: 223). It should be noted, however, that the issue of the ground or justification is not external to meaning: this is the key step in his argumentation. At first sight, singular propositions refer to isolated events (see Dewey 1938: 223). But "were the facts as isolated when the latter is separated from context, the latter would have no more meaning than if uttered by a parrot, and were the sentence uttered by a phonograph, its meaning would be fixed by the context, say of the story or dramatic reproduction in which it appears" (Dewey 1938: 225). In other words, in order to understand any statement that has the past as an explicit object, we need to display its temporal depth, and the conditions of proof for what is said in relation to a concrete problem - that is, it involves in its meaning the unfolding of inquiry itself.

In the end, as Dewey already stated sixteen years before, "the past by itself and the present by itself are both arbitrary selections which mutilate the complete object of judgment" (Dewey 1922: 314). "[T]he past incident is part of the subject-matter of inquiry which enters into its object only when referred to a present or future event or fact" (Dewey 1922: 314). Furthermore, "event is a term of judgment, not of existence apart from judgment" (Dewey 1938: 222). This is why when Dewey claims that "In denying that the past event is as such the object of knowledge, it is not asserted that a particular present or future object is its sole and exhaustive object, but that the content of past time has a future reference and function" (Dewey 1922: 314). He is not granting metaphysical priority to the present or to present experience, nor to merely flowing, as judgments or knowledge always involve a connection, "and, where time enters in, a connection of present with past and future" (Dewey 1983: 47). ${ }^{18}$

Dewey's observations on historical judgment should not seem strange or out of place to our great twentieth-century philosophers of history, Collingwood, Gadamer, Ricœur, White, Danto and Mink. Nevertheless, it is surprising that, despite their family 
resemblances, Danto criticized them fiercely and Mink ignored them altogether. Dewey reflects on the cognitive status of history by wondering: "Upon what grounds are some judgments about a course of past events more entitled to credence than are certain other ones?" (Dewey 1938: 230). Whether it is possible or not to formulate fully guaranteed judgments about the remote past (the skeptic's problem), or if history is a science or not, are matters of no interest to him. Let us quote once again Dewey's precept: "the writing of history is an instance of judgment as a resolution through inquiry of a problematic situation" (Dewey 1938: 231). If this is the case, then his concrete question refers to accepting some (narrative) structures instead of others. Now, although judgments and narrations are made of existential propositions, the meaning of each proposition cannot be isolated from the process of inquiry, nor from its relation to the initial problem. But this trait is not exclusive to history: it in fact belongs to scientific inquiry in general. The logic of inquiry recognizes that every existential proposition must operate "(1) as material for locating and delimiting a problem; (2) as serving to point to an inference that may be drawn with some degree of probability; or (3) as aiding to weigh the evidential value of some data; or (4) as supporting and testing some conclusion hypothetically made" (Dewey 1938: 231). That is, the meaning of the existential proposition is not determined by an independent event or occurrence, but by its role in inquiry. In the specific case of history, existential propositions about facts established under conditions of maximum control (as a result of inquiry in auxiliary sciences) are indispensable "but they are not in their isolation historical propositions at all" (Dewey 1938: 232). It is only in reference to a concrete historical problem that they will become historical propositions. ${ }^{19}$ This leads us to consider what constitutes a concrete historical problem. In broad terms, and according to common sense, historical inquiry is defined as "giving an account of what actually happened" or "determining what and why something happened in the past." But we will not find clear and sufficiently broad notions of "what really happened" and "giving an account of" without referring to the concrete contexts in which inquiry is posed. In relation to this, Dewey was well aware of the self-consciousness that historians themselves show in relation to the selective and presentist nature of historical narratives: "All historical construction is necessarily selective" (Dewey 1938: 234, emphasis added). "The slightest reflection shows that the conceptual material employed in writing history is that of the period in which a history is written" (Dewey 1938: 232-3) Therefore, "if the fact of selection is acknowledged to be primary and basic, we are committed to the conclusion that all history is necessarily written from the standpoint of the present, and is, in an inescapable sense, the history not only of the present but of that which is contemporaneously judged to be important in the present" (Dewey 1938: 234).

In view of the observations made thus far, it is crucial to look into an assertion on the aim of historical inquiry that is more familiar to historians: that is, the reference of history to what "actually happened in this way." According to our philosopher, such a statement "has its status and significance within the scope and perspective of historical writing" (Dewey 1938: 236). And, strictly speaking,

it is a warning to avoid prejudice [...] an exhortation to exercise caution and skepticism in determining the authenticity of material proposed as potential data [...]. It does not determine the logical conditions of historical propositions, much less the identity of these propositions with events in their original occurrence. (Dewey 1938: 236)

27 Now, from my point of view, there is something that must be clarified in relation to this particular issue. Acknowledging that the meaning of "what really happened" is relative to 
a certain perspective is not to say that its value is limited to what is useful or satisfactory. Rather, this perspective urges us to pay attention to the consequences that follow from establishing "what really happened" in the context of inquiry. The specific criteria and reasons of our context of inquiry, in which "what really happened" is stated, are a part of the very meaning of that statement. This is precisely why the display of consequences is a never ending business, and it lacks a predetermined direction. Dewey himself notes that one of the main principles in the logic of historical inquiry is that "the writing of history is itself an historical event. It is something which happens and which in its occurrence has existential consequences" (Dewey 1938: 236). "As culture changes, the conceptions that are dominant in a culture change" (Dewey 1938: 233). "History is then rewritten [...] the new conceptions propose new problems for solution" (Dewey 1938: 233).

Ultimately, his reflections tried to shed light on "the inadequacy and superficiality of the notion that since the past is its immediate and obvious object, therefore, the past is its exclusive and complete object" (Dewey 1938: 237). The past to which our books of history refer is "of logical necessity the past-of-the-present, and the present is the-past-of-afuture-living present" (Dewey 1938: 237). As active beings who interact with our environment, we must deal with a double process. On the one hand, the ever changing environment (natural or social) which throws "the significance of what happened in the past into a new perspective" (Dewey 1938: 238). But, on the other hand, our own activity of inquiry is under constant change, and inasmuch as judgments about the meaning of the past change, those new judgments themselves are, for Dewey, new instruments "for estimating the force of present conditions as potentialities of the future" (Dewey 1938: 238). We need to erase any association of inquiry and narration with images such as building a puzzle with fixed pieces: "No historic present is a mere redistribution, by means of permutations and combinations, of the elements of the past" (Dewey 1938: 238). Inquiring about the past, narrating it, is a problem-solving activity, and as Dewey has aptly indicated, "men have their own problems to solve [...]. In using what has come to them as an inheritance from the past they are compelled to modify it to meet their own needs, and this process creates a new present [...]. History cannot escape its own process" (Dewey 1938: 238). ${ }^{20}$

\section{Danto's Criticism and a Possible Pragmatist Answer}

In his great book Analytical Philosophy of History, narrativist philosopher Arthur Danto has taken note of the reflections brought by pragmatists such as Lewis and Dewey as cases of skepticism in relation to the past. ${ }^{21}$ Historical statements are not about past events; they are predictions about research procedures and their results. For example, the statement "yesterday there was a fire in the car factory" would not be about yesterday and a fire, but rather about twisted metals, smell of smoke, ashes, and so on - that is, traces that would clue us in on the event. What is the problem here? Given that the procedures for detection will take place after the historian formulates the historical statement, its meaning refers to the future, not the past. In Danto's reading, a pragmatist would say that historical statements are ultimately undercover predictions, and what they predict is relevant evidence. 

Not only do they attest the outworn belief that we only know about the past that cannot be witnessed, based on proof; but also, when I formulate a statement about the past, I am implicitly predicting the experiences I will have in the future if and only if I undertake certain actions, "and Lewis' mistake is to suppose that this is all I am doing, that the whole of my cognitive claims are expressed in conditional sentences of the sort we have recognized" (Danto 1985: 43). That is, we do something more, something that the pragmatist withholds from the historian, or withholds from all of us: namely, that we speak about the past, that we know the past or that our statements express knowledge about the past. As Danto explained in "Historical Language and Historical Reality" (Danto 1985), they specifically confuse or fail to distinguish two ways in which language relates to the world through (a) a part-whole relationship, that is, by belonging to the inventory of reality, and capable of sustaining causal relationships, and (b) an external relationship to reality in its entirety, in its representative function, capable of sustaining semantic values (true and false) (see Danto 1985: 305).

There is an inside and an outside of reality: paintings, maps, concepts, ideas, art have - as does language - this twofold relationship with the world. The particular case of "historical language" (that is, the sentences which, when stated, aim at describing an event previous to its utterance or inscription), implies as truth condition, a sentence in the past tense. "Fernández is an ex-president" implies, first of all, that "Fernández was a president." Secondly, satisfying this truth condition implies in turn the actual occurrence of some event previous to its utterance. In sum, historical sentences lie, by their own nature, in history; if they are true, they are actually subsequent to the events described in them. Nevertheless, in their attempt to describe the past, historical sentences are external to the past, and claim to be true. Therefore, the fact that historical sentences allow for temporal, truthful connections with the events they describe is a symptom that historical sentences are within and without the reality they describe, and this is why their combined semantics generates problems in philosophy of history (see Danto 1985: 311-4).

utterance "to be historical" does not add any further information about the event (it belongs to what it isolated as language in its relation to the world as part-whole, not as an occurrence in the world). It does not add information on the external descriptive relationship between language and reality (in its representative function).

What makes a sentence true is not affected by the moment in which such sentence is uttered. As Danto has argued extensively in his famous piece "Narrative sentences" (Danto 1985: 143-82), temporal distance of historians and their retrospective position give them an advantage to truthfully know what happened. The possibility of formulating true statements about the past only comes by later, and sometimes much later, than the occurrences. But whatever it is that makes them true does not depend on those who are able to find it out or prove it.

In short, we are faced with two ways of approaching the question of the correct representation of the past: (1) What is the relationship between representation and reality?; and (2) how can we legitimately represent the past or reality? ${ }^{22}$ The first question begins with the establishment of two different ontological orders; the aim is to connect them, in order to unveil the conditions for knowing the past. Worse still, pragmatism grants skeptics their conclusion about the futility of the realist pretense that past events in themselves are not only an object of our knowledge, but also the references of our sentences. Now, at this point we should remind Danto that it is precisely

European Journal of Pragmatism and American Philosophy, VIII-2 | 2016 
pragmatism that questions the possibility of isolating the meaning of any given proposition from its context of utterance, which includes the question that is answered by the proposition. Determining the past event that serves as reference is the very result of the research, not its starting point. ${ }^{23}$

These observations deserve a last, critical clarification. Danto, as an analytical philosopher of ordinary language, approaches the subject with an analysis of "the sentence in the past tense" (the narrative sentence), whereas Dewey, whose work is previous to the linguistic turn, approaches the matter in terms of "judgments about the past." This does not stop Danto from applying his criticism, nor does stop us from taking part to the discussion. ${ }^{24}$ Strictly speaking, for Danto beliefs, sentences (language), theories, judgments, belong to the realm of representation, which is ontologically heterogeneous from reality (Danto 1985: 311). In this respect, the relevant question in relation to our knowledge of the past is to elucidate the relationship between representation and reality (that is: what makes a representation true?), which should be distinguished from the epistemic problem of how to know whether the events actually occurred. Let us return once more to Dewey's words:

The propositions that are accumulated about past facts and facts now observable are but means to the formation of this historic narrative judgment. In themselves they are so many separate items. (Dewey 1938: 229)

To which he immediately adds:

There is no such thing as judgment about a past event, one now taking place, or one to take place in the future in its isolation. The notion that there are such judgments arises from taking propositions that are indispensable material means to a completely determined situation as if they were complete in themselves. (Dewey 1938: 230)

In Danto's view, pragmatism is skeptical, but we should add that it is so in relation to the possibility of answering affirmatively to a requirement that is posed by skepticism itself: showing a reality independent from our beliefs (something necessary to rebut skepticism). Nevertheless, it is my understanding that the most important point to stress about this debate is that pragmatism is rather skeptical about the possibility that proposals such as Danto's play any concrete role for solving concrete historiographical problems or controversies. Is this Dantian answer the only way to solve rationally (without resorting to force, or deception) the problems related to the representation of the past? It is time to settle these issues by returning to the question about who killed LV.

\section{Which Bullet Caused the Victim's Death?}

Let us analyze an array of descriptions regarding Liberty Valance's death, and then compare Danto's position with the one defended by Dewey. ${ }^{25}$

1. The bullet in the revolver caused the victim's death.

2. The bullet in the rifle caused the victim's death.

3. Senator Stoddard is the man who killed LV (in 1910).

4. Stoddard killed LV.

5. Doniphon killed LV.

6. The bullet that killed LV came out of Stoddard's revolver.

7. By shooting LV, Stoddard turns Shinbone into a modern, democratic city. 
8. This bullet turned Shinbone into a modern, democratic city

a. Semantic issues, which are sub-divided into:

a.i) meaning,

a.ii) their truth value,

a.iii) the satisfaction of their truth value. occurrence of a past event. relationships between them. him. (as in the case of narrative sentences).

b. Epistemic issues, that is, the concrete conditions of proof or verification of the sentences.

All these different descriptions (1 to 8) share the same grammar, as they are in the past tense (or in the historical present tense, as in sentences 3 and 7) and, as such, they talk or are about the past. Nevertheless, according to Danto, not all of them do it in the same way, and as a consequence not all could be uttered truthfully by anyone at any point in time. They all speak about an event which is previous to their utterance, but not in the same manner. Sentences 3, 7, and 8, for instance, are an example of what Danto called narrative sentences: sentences that describe a past event in terms of another one that happened later in time, perhaps even at the time of utterance. ${ }^{26}$ As a consequence, the contemporary subject would be as such unable to know its truth (the issues addressed in point b); an eyewitness would not be able to affirm it truthfully at the moment of the occurrence. ${ }^{27}$ But in every case the meaning of the sentence includes or implies the

I would like to draw attention to the case of narrative or historical sentence number seven. It entails as a truth condition, following Danto, a sentence such as 4 or 6 , depending on whether we describe the event in physicalist or in intentionalist terms. And, in turn, the satisfaction of its truth requires that an event described in the terms of such sentence must have actually taken place. Let us take a close look. Sentences 1 to 8 describe some event in the past (again, at this stage we are not asking whether this is the same event under different descriptions, or different events altogether). The important issue here is that at first sight there are differences between them in relation to the language game chosen to talk about reality in general, and social reality in particular.

1 and 2 describe events in a physicalist language, which mainly reveals the causal

$3,4,5$, and 7 clearly describe actions, are presented in an intentionalist language, and are understood within a teleological structure, formulated as means-to-ends.

6 is ambiguous or unclear as to its status, since it could mean both that Stoddard himself purposefully killed LV with a shot, or that the bullet came out of his revolver in a series of defensive moves (not necessarily voluntary), whereas Stoddard did not want to shoot

For Danto, one event can bear different descriptions, both in relation to its being described in an intentional language or a physicalist one (what is usually called the language of events, as something different from actions) and in relation to the subsequent "redescriptions produced by its consequences in the future of its occurrence"

46 Reference, meaning, or that of which the statement speaks and makes it true, is the occurrence of the event. At this stage we could say that Danto is bound to an idea of event without a description, or the idea of a basic description of an event. Either way, we are faced with the need to clarify what an event without a description or a basic event 
description would be. This last point, to which Danto's argument leads us, is the one that will prove problematic for a non-skeptical consideration of our knowledge of the past: it leads us to posit a reference for historical sentences that is unaccessible in itself, and therefore cannot be our guarantee for rejecting skepticism.

What would a pragmatist interested in historical narrative or a pragmatically informed narrativist say? In search of an example, we can go back to the case of narrative or historical sentence number seven. Following Danto, we would say that it entails as its truth condition a sentence such as 1,4 , or 6 (depending on whether we describe the events in physicalist or in intentionalist terms), and the satisfaction of its truth requires that an event described in the terms of such sentence must have actually taken place. Now, what do we mean when we say that the three sentences refer to the same event, be it narratively or not, be it in physicalist or intentionalist language? What lies at the basis of every description, making it true? How do we determine whether the sentence implied in 7 is the first - "The bullet in the revolver caused the victim's death" -, the fourth "Stoddard killed LV" -, or the sixth one? - "The bullet that killed LV came out of Stoddard's revolver." Do we decide it by referring to the occurrence or to the future implications of the description, whichever it is? What is more, choosing one or the other has important consequences, be it by allotting responsibility or by alleviating it (a lost bullet). In other words, here we see clearly why, according to pragmatism, the meaning of any empirical sentence about the past or in the past tense, refers to the future. Now we can understand Dewey when he says that

The past occurrence is not the meaning of the propositions. It is rather so much stuff upon the basis of which to predicate something regarding the better course of action to follow, the latter being the object meant. It makes little difference whether the past episode drawn upon is reported with literal correctness or not. (Dewey 1922: 43-4)

This is the case for those sentences that describe events in a physicalist language, in an intentionalist one, or in narrative descriptions (inaccessible to contemporary subjects). Their correct meaning cannot be decoupled from the future consequences of such descriptions.

In 1929 Lewis noted that meaning and truth of an empirical statement - such as number 1 in our example: "The bullet in the revolver caused the death of the deceased" - entails the fact that "To ascribe an objective quality to a thing means implicitly the prediction that if I act in certain ways, specificable experience will eventuate" (Lewis 1929: 140). In our case, if I believe that a certain bullet caused this death, we should be able to detect certain marks in the body, the rifle, and so on, and these actions are subsequent to the alleged occurrence of the atomic event. But the same thing would happen if we move in the context of intentionalist language: we would always assign properties or offer descriptions which, by assuming them, engage us with other descriptions and with registering or collecting certain testimonies. In short, summarizing the debate, Danto and the pragmatists (Dewey and Lewis in the case at hand) would agree on the complexity of determining who killed LV, since this requires us to:

1. decide the language in which the matter will be addressed (physicalist or intentionalist);

2. search for relevant evidence, and in the specific terms of whichever language game we adopt (physicalist or intentionalist);

3. finally, with regards to whether we want to or must reveal (or not) which bullet killed LV, or caused the death, or whatever, accept that these are matters settled in terms of 
consequences and evidence. Moreover, they are not settled once and for all, and can be reopened over and over again, from the present of whoever intends to reopen it. past tense, and thus previous to the formulation of the problem, does not add or subtract anything to the resolution of the matter. On the contrary, the meaning of a proposition in the past tense is not limited to an alleged reference without description, or with some kind of basic or contextually neutral description. It refers implicitly to socially shared procedures of justification in the future. My main point here has been to show the inextricable bond between that pragmatist argument and the detailed and rich considerations offered by literary theory about the variety of descriptions offered by intentional language, and their consequences. In his classic A Grammar of Motives, Kenneth Burke wonders:

What is involved, when we say what people are doing and why they are doing it?" And "any complete statement about motives will offer some kind of answers to these five questions: what was done (act), when or where it was done (scene), who did it (agent), how he did it (agency), and why (purpose). (Burke 1945: XV)

Not only are the various combinations of possible answers determined by the events in themselves, but they also reveal different conceptions of the world. And again, which conception we choose will have practical consequences for life. ${ }^{28}$

Why would this be a case of skepticism? According to Danto, because it has not presupposed a reality independent of the past as a referent for our statements about it. It is time to address this issue with the help of Mead.

\section{Mead and the Re-Writing of History}

Philosophers have repeatedly addressed a playful skeptical argument about the past, according to which it is logically possible that the world as we know it, even with our memories and fragments of evidence of times past, was created a few minutes ago (five or thirty, little changes). ${ }^{29}$ If this is the case, statement as "Julius Caesar crossed the Rubicon in 49 B. C." or "my mother was born in 1937" lack a reference; therefore, either all statements are false, or the problem of their truth will not emerge. In order for this argument to hold, it is not necessary that the world actually started a few minutes ago; we only need to be able to imagine the possibility that it did. It could have started a few minutes ago or not, we can have success or not when talking truthfully about the past, but unfortunately if we follow this argument, we cannot know whether it started or not, whether we will be able to say true things about the past or not, because all evidence is compatible with either possibility. Now, if this argument is unassailable, its reach is so 
broad that it would not only affect historical knowledge, but knowledge of all kind. In conclusion, we cannot doubt history without putting at risk our beliefs across the board..$^{30}$

In his "The present as the locus of reality," included in the posthumous publication The Philosophy of the Present, George $\mathrm{H}$. Mead addresses the skeptical argument ${ }^{31}$ inquiring the relevance of the existence of a past independent from the present for our experience, and for that of the scientist and the historian. What difference would it make to our inquiry, were we to accept not only the reality of the past, but also its irrevocability, regardless of what happened later on? What would it be the importance of the idea that nothing that happened after the occurrence of that past would be able to change its universal or eternal characteristics?

I suggest we approach Mead's account in connection with Dewey's idea, surveyed earlier, that "the writing of history is itself an historical event. It is something which happens and which in its occurrence has existential consequences" (Dewey 1938: 236). So, a deeper question here is who "we" are or who this "we" to whom knowing the past involves a complete change of their own existence is. It is important, however, to bear in mind Mead's contribution to social psychology as conveyed by what he called "social behaviorism," ${ }^{32}$ and its consequences for an understanding of human beings as subjects thinking in communicative terms. That is, thought and knowledge emerge in novel ways from the activity (interaction) of the organism with its environment. Of course, reality is the reality of our experience in the present, but the present or presents are dense and diverse in their temporal range; they imply a future and a past to which we deny existence..$^{33}$ The density of the present is manifest in its own identifying traits: becoming and disappearing, coming to be and ceasing to be. Therefore, experience (present, the specious present, or, passage), according to Mead, is a vital process of self-adjustment between an organism and its environment. ${ }^{34}$ So, is the reality of the past of that organism independent from it? Is there anything like a fixed and irrevocable past? Mead avoids the skeptical challenge by posing the question in relation to our own experiences, so that the past or pasts which we face are both revocable and irrevocable. They are irrevocable in that even when historians can reconstruct what happened, and give an authenticated explanation, they will prevent the reconstruction made by historians in the future from differing from ours. But they are also revocable because the world of future historians will not be able to differ from the present, unless it rewrites the past that is now behind us. The end or meaning of "what it was" belongs to the same present in which that "what it was" is explained. Such "what it was" is so for me or for us now, in our present, and will eventually change into another present. In Mead's words, "against this evident incidence of finality to a present stands a customary assumption that the past that determines us is there. The truth is that the past is there, in its certitude or probability, in the same sense that the setting of our problems is there" (Mead 2002: 37).

Mead would concede that what already happened is irrecoverable. However, we need to bring the real past face to face with the present, from the viewpoint of emerging phenomena, of the occurrence of that very surfacing phenomenon. The past that we now observe from this viewpoint is another past, a different one. Why is that so? By definition, the things that emerge are not a necessary consequence of the past; before they emerged, the past was in fact not a past of those things. Nevertheless, once they have emerged, the connection with the past they followed can be discovered. In other words, the past can be reconstructed, but that reconstruction is a redescription that shows the elements that emerged in the present as following from that past (see Mead 2002: 36). As Mead has 
shown in "The objective reality of perspectives" (2002: 171), the reconstruction of the past in a present is part of that happening, as it emerges from the process - a selfadjusting process of the organism with its environment. Perspective does not consist in thoughts from God's viewpoint, or from one external to the process itself. Rather, it is a novel event, undetermined though conditioned by the environment locating the problems that promote a redescription or articulation of the system. There is no idealism (a pure game of ideas) or determinism (reality or past reality determining the ideas of them).

In 1965, Danto offered a completely different answer. He ignored Mead's writings, and therefore the contrast among them is an exercise in heuristic. Danto's approach stems from a very different way of conceiving the adequate method of posing philosophical problems. As we have seen, pragmatism expresses the fundamental philosophical issue in terms of how certain beliefs or commitments contribute to investigating or solving concrete problems. Danto, on his side, contends that philosophical approaches are set in terms of the identity of indiscernibles. Following the skeptical conjecture, it could be possible that two objects which satisfy descriptions in terms of a Ming bowl - that is, two materially indiscernible objects - do not belong to the same kind of object: one is genuine and the other is just a reproduction..$^{35}$

If we remove historical descriptions from our language, certain objects in the world such as an original Ming bowl inside the museum and the reproductions that decorate my house - would be indiscernible.

61 If we restore historical descriptions in our language, they would be different objects: one being an original Ming bowl, the other a reproduction, even if none of these differences would be manifest to the anthropologically educated eye.

Danto invites us to note the extent to which our beliefs about the past penetrate the language we use, even to describe contemporary objects with those descriptions: the socalled "present world." The skeptical challenge is incompatible with any ordinary historical statement applied to the present world. If for one crazy second we believed that the conjecture is true, then all historical statements would all of a sudden become false, all the areas of language left out of the game, and we would lose interest in them, from a historical point of view, both if our beliefs were true and if they were false.

It must be said that we are dealing with two sophisticated stances on knowledge of the past and of history, which take seriously into account the fact that historians are also historical agents, that historical perspective is a part of history, and that it is up to every history to tell or narrate histories that are not only true, but also relevant to the historian's present. Precisely Danto repeated over and over again that "to exist historically is to perceive the events one lives through as part of a story later to be told" (Danto 1985: 343). Nevertheless, Dewey's and Mead's considerations must be appreciated in the context of a deep criticism of fundamentalism, of atomistic empiricism, and of the mind/world dualism. Because no concept has a denotation that goes beyond the given. It is as if Danto had remained trapped in the "given vs. constructed" dualism, whereas pragmatism, by virtue of its interest in the basic nature of the idea of "activity," advances towards a notion of knowledge as the activity of an organism in its environment. As pragmatist philosopher Richard J. Bernstein has noted, these early considerations successfully avoided the "Cartesian anxiety" informing the search of an independent reality as the grounds for knowledge. Once the ontological heterogeneity (or dualism) 
between mind and body (world) has been established, the problem of its connection becomes unsolvable (Bernstein 1983: 31).

\section{Conclusion} be read in two ways. One of them, extremely narrow and even malicious in a way, would stress that if meaning is related to justification, and if this depends on fulfilling a specific interest in the given context, then once the interest is fulfilled this would be enough for justification. As a consequence, when we face two alternative interpretations, to the extent to which each one satisfies the interest of those promoting it, either they are both justified, or the notion of justification is not applicable in any interesting way. Hence relativism and arbitrariness (Wilkins 1959). unfinished, and any consideration has an undetermined number of possible consequences. And this is not only the case from a logical and abstract point of view, but also from a heuristic one, that is, from the point of view of the practice of inquiry itself. This cannot in fact be reduced to the logic of inference between atomic and isolated propositions, but rather it answers to the logic of questions and answers of social beings situated in concrete contexts which face them with concrete problems.

In this paper, I have faced a double challenge. On the one hand, I attempted to show that nowadays a pragmatist philosophy of history (inspired by Dewey and Mead), concerned with the consequences that follow from our assertions about the past, is unlikely to be alien to the proposals of new NPH, particularly the orientation which has focused its attention on narrative writing of history, and turned to literary theory with the purpose of pondering the consequences of the diverse descriptions of our past human world. On 
the other hand, I sought to stress how narrative philosophy of history would be strengthened by taking up pragmatism seriously.

The lengthy analysis of The man who shot Liberty Valance allowed us to appreciate the deep complexity of solving a historical problem, even in the case of those referred to an allegedly concrete historical event which, precisely because of this, should not be too arduous. Nevertheless, its resolution does not only involve a factual aspect: answering the question of "which bullet caused LV's death?" requires taking decisions about the very language in which the events will be framed, depending on the importance of their resolution for the present or for a moment subsequent to the event. As a consequence, this matter is inherently related to another question: "what difference would determine which bullet caused the death make for our future decisions?" Common sense would have that we are in the presence of two different kinds of questions, since one depends on what actually happened, independently of our interests, whereas the other depends on what our interests (or those of whoever actually poses the question) are. As they are different questions, the logic of their justification is supposed to be different as well. One depends on reality, while the other on values. Pragmatist philosophy will dissolve this apparent difference without renouncing either the possibility of historical knowledge or a rational reconstruction of controversies. But as we have tried to show, the basic choice between a language of motives (intentional) and a physicalist one is not defined by referring to the event itself in the past. The validity of the description, as well as its understanding, requires deploying the future consequences of the descriptions we adopt according to our problems of inquiry and to the processes to verify such consequences. This is not skepticism or lack of rationality; rather it is a warning about all the implications of any given description; this is why we are committed to acknowledging its consequences in the future.

\section{BIBLIOGRAPHY}

ANKERSMIT F., (1983), Narrative Logic: A Semantic Analysis of the Historian's Language, Dordrecht and Boston, Martinus Nijhoff Philosophy Library.

ANKERSMIT F., (1994), History and Tropology. The Rise and Fall of Metaphor, Berkeley/ Los Angeles/ Oxford, University of California Press.

ANKERSMIT F., (2002), Historical Representation, California, Stanford University Press.

ANKERSMIT F., DOMANSKA E., \& H. KELLNER, (2009), Re-figuring Hayden White, Stanford, Stanford University Press.

BERNSTEIN R. J., (1983), Beyond Objectivism and Relativism. Science, Hermeneutics, and Praxis, Philadelphia, University of Pennsylvannia Press.

BLAU J., (1960), “John Dewey’s Theory of History,” Journal of Philosophy, 57, 3, 89-100

BURKE K., (1945), The Grammar of Motives, Berkeley, University of California Press.

CARR D., (1986), Time, Narrative and History, Bloomington Indianapolis, Indiana University Press. 
ColLINGWood R. G., (1994) The Idea of History, revised edition, Oxford University Press.

DANTo A., (1985), Narration and Knowledge, New York, Columbia University Press, [with the complete version of Analytical Philosophy of History, ed. 1965].

DANTo A., 1997) Connections to the World. The Basic Concepts of Philosophy, Berkeley, Los Angeles, London, The University of California Press.

DEWEY J., (1922), “Realism without Monism or Dualism -I.: Knowledge Involving the Past,” The Journal of Philosophy, Vol. 19, No. 12 (Jun. 8, 1922), 309-17, J. A. Boydston (ed.), 1983 John Dewey The Middle Works, 1899-1924, Volume 13, Carbondale, Southern Illinois University Press, 40-9.

DEWEY J., 1938) Logic: The Theory of Inquiry. Chapter 12: "Judgment as Spatial-Temporal Determination: Narration-Description," in J. A. Boydston (ed.) 1986, John Dewey The Later Works, 1925-1953, Volume 12, Carbondale, Southern Illinois University Press.

DORAN R., (ed.) (2013), Philosophy of History after Hayden White, London, Bloomsbury.

FOGU C., \& K. PIHLAINEN, (eds.) (2014) “Metahistory Forty Years Later," Storia della Storiografía, 61, 1, 11-205.

JOHnSon Dorothy M., (1953), “The Man Who Shot Liberty Valance," in Ead., Indian Country, New York, Ballantine Books.

KELLNER H., (1989), Language and Historical Representation. Getting the Story Crooked, London, The University of Wisconsin Press.

LEWIS C. I., (1929), Mind and the World-Order, New York, Chicago, Boston, Charles Scribner's Sons. MCBRIDE J., (2011), Searching for John Ford, Jackson, University of Mississippy Press.

MEAD G. H., (1972 reimpr., [1934]), Mind, Self, and Society, The University of Chicago Press.

MEAD G. H., (2002 [1932]), The Philosophy of the Present, Amherst, New York, Prometheus Books.

MINK L., (1987 posthumous edition), Historical Understanding, Brian Fay, Eugene Golob \& Richard Vann, (eds.) New York, Cornell University Press.

MURPHEY M. G., (2009), Truth and History, New York, State University of New York.

RICGUR P., (1983), Temps et récit. Tome I: L'intrigue et le récit historique, Paris, Le Seuil.

Tozzi V., (2012) "Pragmatist Contributions to a New Philosophy of History," Pragmatism Today, 3, $1,121-31$

Tozzi V., (ed.), (2013), "Hayden White Metahistory 40 years later," Metatheoria. Revista de filosofía e historia de la ciencia, 4, 1, 1-110

TOzZI V., (2016), “White, Burke and the "Literary" Nature of historical controversies," in E. Morales-López \& A. Floyd, (eds.), Developing New Identities in Social Conflicts: Constructivist Perspectives on Rhetoric and Discourse Studies, John Benjamin, (forthcoming).

WHITE H., (1973), Metahistory. The Historical Imagination in the Nineteenth-Century Europe. Baltimore, Johns Hopkins University Press.

WHITE H., (1999), Figural Realism, Studies in the Mimesis Effect, Baltimore, Johns Hopkins University Press.

White H., (2014) The Practical Past, Evanston, Northwestern University Press. 
WILKINS B. T., (1959), "Pragmatism as a Theory of Historical Knowledge: John Dewey on the Nature of Historical Inquiry,” The American Historical Review, 64, 4, 878-90.

\section{NOTES}

1. Translated by Moira Pérez.

2. I am talking about the explanation vs comprehension debate that took place mostly in the nineteenth and twentieth centuries.

3. I name the most remarkable ones.

4. The point on which pragmatism can shed some light is that the correctness or incorrectness of any judgment or description of the past is not determined by something like the occurrence in itself, but rather by the consequences that follow from a determining description or judgment. I work this particular issue more in depth in Tozzi 2016. I will return to this matter in section 5.

5. Such are the cases of Erich Auerbach, Kenneth Burke, Northrop Frye, Roman Jakobson, and we should also mention the works of Gombrich and Goodman on theory and philosophy of arts.

6. See Murphey 2009.

7. See White (1999: 2), where he distinguishes information about the past and historical discourse, and White 2014, where he distinguishes the practical and the historical past. See also Ankersmit 1983 and 1994 where he distinguishes historical research (questions of facts) and historical writing (questions of interpretation).

8. See Ankersmit, Domanska \& Kellner 2009; Doran 2013; Tozzi 2013; Fogu \& Pihlainen 2014.

9. In Dewey 1922 (reprinted in 1983) and 1938. NPH is a reaction to the dismissal of narrative history that took place in the first part of the twentieth century. The so called "Covering Law" model (in philosophy) and the École des Annales (in history) considered Narrative History as a prescientific activity. What makes Dewey's account the most interesting one is the fact that he saw neither a fault in the narrative way of historical writing nor the necessity of some alternative logical reconstruction of historical inquiry. There is another interesting fact: his specific remarks on the writing of history reveal his watchful eye on the historical practice, enabled by his active participation in historical debates about the nature of history with other historians. On the relationship between Dewey and American historians see Blau 1960 and Wilkins 1959.

10. Dewey (1922: 314).

11. Mead 2002.

12. I arrived at Mead through Habermas. I was very interested in the connection he makes between Mead's Mind, Self, and Society and other social theories interested in communicative aspects of common world and social relationships (Mead, Schütz, Gadamer, Wittgenstein, and Winch). Then I discovered The Philosophy of the Present, and I found myself completely surprised because one of the main skeptical arguments discussed by Danto in his 1965 work is the same argument discussed by Mead in this book, but Danto ignored Mead, and never quoted him. On the other hand, I discovered Dewey's text on the philosophy of history through Danto. He treats pragmatism as an example of skepticism. (I discuss Danto's account in sections 4, 5, and 6). As the reader can see, I studied these two authors in the context of the philosophy of social sciences and of history past the linguistic turn.

13. Ford appoached the dichotomy between telling the truth about the past or telling the most useful story for the Nation in two movies: Fort Apache (1948) and The Man Who Shot Liberty Valance (1962). Both movies lead the same moral (the most useful stroy is the one to be told). The difference between them is that one of the main characters in Fort Apache, Liutenant Colonel Owen Thursday (Henry Fonda), is a fictionalized version of General George Armstrong Custer, and the events depicted in the movie make reference to "[Custer's] reckless expedition into sioux 
territory in 1876 that led to the massacre of the entire battalion of Seventh Cavaltry at the Little Bighorn" McBride (2001: 449-50). On the other hand, the plot of The Man Who Shot Liberty Valance was adapted from a short story written by Dorothy M. Johnson (1953) and, of course, the controversial event is not a historical event for us but it is a historical event in the film. I have chosen to work on the 1962 film because although the past event is not a historical event (and the researchers depicted in the movie are journalists, not academic historians), the case remind us of Collingwood's well-known crime story "Who killed John Doe?" through which Collingwood illustrates the work the historian does with evidence, using the "logic of questions and answers" as the correct method of enquiry (Collingwood 1994).

14. Or, a third option he could have evaluated the issue from a strictly personal point of view, that is, paying attention to what he, as a moral agent, should do beyond convenience or utility.

15. Giving a deeper but complementary account to his earlier reflections from 1922.

16. In fact, as we will see at the end of this section, Danto's criticism of pragmatism (as a form of skepticism) is grounded in his compromise with representationalism.

17. "[T]here are no different kinds of judgment, but distinguishable phases or emphases of judgment, according the aspect of its subject-matter that is emphasized. In the opening statement existential transformation is the point of emphasis" Dewey (1938: 220). "Existential subject-matter as transformed has a temporal phase. Linguistically, this phase is expressed in narration [...] all changes occur through interactions of conditions. What exists co-exists, and no change can either occur or be determined in inquiry in isolation from the connection of an existence with co-existing conditions" (Dewey 1938: 220, emphasis added).

18. Dewey, Mead, and Danto all rejected the account of present time as an atomic instant. They considered the present as thick present or specious present. See Dewey (1922: 309); Mead (2002: 35); and Danto (1985: 84). Mead talks about the present as passing. Danto talks about past-referring terms (like scar, widow or divorced), which describe some present feature but they can only be rightly attributed in the case of specific events having occurred in the past - being wounded in the first case, married in the second. See Danto (1985: 71).

19. Let's pay attention to the similarity between this sentence from Dewey and White's account on documentary evidence. The latter says that his thought about "historical discourse does not imply that past events never really existed [or] that we cannot have more or less precise information about these past entities [...] information about the past is not in itself a specifically historical kind of information [...]. Such information might better be called archival, inasmuch as it can serve as the object of any discipline simply by being taken as a subject [...] it is only by being made into the subject of historical discourse that our information about and knowledge of the past can be said to be historical" (White 1999: 2).

20. I need to make clear a point about Dewey's notion of narration. As I have already said at the beginning of this section, Dewey introduced the concept in the context of his logic of inquiry and in the context of the theory of the temporal and historical phase of judgment. However, it is important to note that his account on historical writing expresses the common sense of historicist ideas of historical research. For that reason, it is very difficult not to connect these few pages on history to the ideas of those thinkers who were critical of positivism (like Croce or Collingwood). The similarity between Dewey's text on the writing of history and Collingwood's "epilegomena" is remarkable, both of them were critic of the common sense belief in the authority of personal memory and witness testimony to corroborate historical interpretations. According to Collingwood, "historical image" (or narration) is constructed and evaluated by historians in response to the interrogations of their age. On the other hand, every answer will give place to new questions. Historians themselves are part of the historical process and each age poses new and different problems. Historical testimony changes with each change of the historical method, each new generation has to rewrite history in its own terms because it has to 
review its questions. The interesting thing about these remarks is to point out to the fact that Dewey found those ideas of history compatible with his logic of inquiry.

21. In the present paper I am not providing an in-depth account of Lewis' thoughts. I refer to Lewis because Danto presented his criticism against pragmatism by discussing Dewey and Lewis, and I refer to some of Lewis's insights on knowledge of the past only when they are clearly connected with some of Dewey's similar insights. On the other hand, I am completely aware that Lewis deserves a special space (which I do not have here), but, more importantly, I am not claiming that Lewis' pragmatism is similar to Dewey's.

22. Danto explains his account on the correct form of philosophical problems in Danto 1997.

23. See the definition of judgment at the beginning of section 3 above.

24. I want to make clear that Danto's account of Dewey as a case of skepticism is completely unfair. Danto's view is not the result of either some misunderstanding or of the fact that both philosophers belonged to different times and different philosophical movements. Although it is true that Dewey predates the linguistic turn, he was explicit, on one hand, in his intention to avoid approaching the logic of inquiry based in the analysis of the singular proposition in isolation of the context of inquiry and its relation to the specific problem to be solved, and, on the other hand, in rejecting dualism and representationalism, because they both lead to skepticism.

25. I will not consider, for the moment, whether all these sentences are descriptions of the same event. I will return to the question of what would be a "naked" event devoid of any description a little later.

26. "Their most general characteristic is that they refer to at least two time-separated events though they only describe (are only about) the earliest event to which they refer" (Danto 1985: 143).

27. A contemporary witness is not allowed to truthfully describe events if that description refers to a future event.

28. White took in account Burke's pentad and tropology in Metahistory in order to disclose the basic ontologies that inform the differences among several historical accounts.

29. This argument is not strictly general given that statements that refer to the past five minutes are not affected. But, as Danto himself states, what historian would be interested in that brief moment of time? See Danto (1985: 31).

30. Danto's notion of present implies extension, duration, and speciousness. "To be a thing is to have extension and duration, and to deny either of these is to deny the existence of things [...] and surely one must run a race on order ever to be said to have won one" (Danto 1985: 84-5).

31. Mead vaguely attributes to Father Gosse, a 19th Century creationist, the idea that the world might have been created only five minutes ago.

32. By virtue of its behaviorist approach, Mead's theory overcomes introspection, Cartesianism and idealism. Through its social approach, it surpasses the individualism to which Watsonian behaviorism remained attached. Mead 1972.

33. "The specious present of a human individual would presumably be a period within which he could be himself" (Mead 2002: 49).

34. As I argued in Tozzi 2012, emergentism is, first of all, a kind of historical heuristic, since it allows us to track the appearance of human faculties and processes of extreme complexity, without presupposing an individual or a mind apart from the process of emergence itself, and without appealing to any a priori contents. It thus enables the dissolution of dualisms such as subject/object, mind/world, individual/society. Secondly, it invited the dissolution of the dualism between historical knowledge (unfixed, changing and discontinuous) and the actual past (fixed and irrevocable) at the roots of historical skepticism.

35. In other words, both bowls satisfy, from a material point of view, the narrative sentence that refers to a past event (or object) Ming China (Danto 1985: 335). 
36. When I talk about "our beliefs about our world" I mean personal beliefs of our own past and historical interpretations, memory politics and substantive philosophies of history. That is, all account of the past interested in its truth as well as in its meaning.

\section{ABSTRACTS}

The second half of the twentieth century has been witness to a blooming of reflections on the status of historical narrative. One of the main achievements of a narrativist philosophy of history (NPH) consists of having reinforced the worth of an autonomous historical knowledge vis à vis standard conceptions of science which made history appear as underdeveloped. Although NPH does not dismiss the importance of documentary evidence, it did not produce an integrative account of both dimensions (the work of writing and the work with evidence), being slave of a number of epistemological dualism. On one hand, NPH seems to remain in the representationalist paradigm in the case of evidence, while, on the other hand, it only admits pragmatic evaluation in the case of narrative discourse. In this paper, I sustain that John Dewey's and George H. Mead's reflections on our knowledge of the past offer NPH good reasons to assess the role that literary theory can play in reconstructing historical controversies, without neglecting the importance of empirical research. For instance, Dewey holds that historical writing is a case of the judgments produced in response to problematic research situations. By virtue of this, the meaning of judgments referred to the past (that is, historical narrations) "have a future reference and function," and thus understanding their meaning involves displaying the consequences that follow from such judgments. Mead, for his part, has argued that by appealing to the independent reality of the past as ground for our beliefs about it, rather than contributing to the rational resolution of our historical problems, we stray towards the search of something which is by definition unattainable. As a consequence, I shall show the urgency of advancing in the development of a narrativist, pragmatistically-informed philosophy of history. My considerations will be illustrated through the analysis of a controversial case about a past event: the main plot of the memorable film The man who shot Liberty Valance, by the equally memorable John Ford.

\section{AUTHOR}

\section{VERÓNICA TOZZI}

Universidad de Buenos Aires, Universidad de Tres de Febrero, CONICET

veronicatozzi[at]gmail.com 